\title{
Polysèmes
}

Revue d'études intertextuelles et intermédiales

$21 \mid 2019$

(Re)constructions

\section{John Fuller in Collaboration with David Hurn and Others to Rebuild Childhood in Times of Crisis}

\section{Aurélien Saby}

\section{(2) OpenEdition}

\section{Journals}

\section{Electronic version}

URL: http://journals.openedition.org/polysemes/5078

DOI: 10.4000/polysemes.5078

ISSN: 2496-4212

\section{Publisher}

SAIT

\section{Electronic reference}

Aurélien Saby, « John Fuller in Collaboration with David Hurn and Others to Rebuild Childhood in Times of Crisis », Polysèmes [Online], 21 | 2019, Online since 30 May 2019, connection on 11 June 2019. URL : http://journals.openedition.org/polysemes/5078; DOI : 10.4000/polysemes.5078

This text was automatically generated on 11 June 2019 .

Polysèmes 


\title{
John Fuller in Collaboration with David Hurn and Others to Rebuild Childhood in Times of Crisis
}

\author{
Aurélien Saby
}

The chimneys have fired their guns And the tower has rung its bell Where chimes that hung in tons Made the turf tremble. Wherever there are boys And a bit of grass or a wall You'll find arms and legs and a noise About nothing at all.

John Fuller, Writing the Picture, 86

1 John Fuller's poetry involving children is often fraught with tension, notably threats relating to the passing of time ("the tower has rung its bell"), or to looming heavy structures making "the turf tremble" while some boys are happily playing on "a bit of grass". Although Fuller wrote several books for children, this article will exclusively focus on his poetry for adults about childhood, and more precisely on texts inspired mostly by photography, but also on lines composed to be set to music. From the late 1980s onwards, Fuller started writing poems intended to illustrate several pictures taken by his friend David Hurn (Magnum Photos) between 1966 and 2009. Their book entitled Writing the Picture (2010) (henceforth WP) results from an unprecedented collaboration where Hurn's photography sparks a poetry explored by Fuller through thought-provoking verse. Following in the footsteps of Robert Capa or Henri Cartier-Bresson, Hurn successfully captures the graceful vitality of childhood in a number of snapshots, including impromptu outdoor games whose energy is enhanced by Fuller's short, lively lines through cinematic metonymies of the players' bodies or zeugmas adding sounds to the photos: "Wherever there are boys / [...] You'll find arms and legs and a noise". 
2 Yet Hurn and Fuller share a deep concern regarding the sensitive issue of sacrificed childhood in times of crisis, be it an industrial crisis when "[t]he chimneys have fired their guns" (i.e. when the factories have just closed), the collapse of a colliery spoil tip as happened in Aberfan in 1966, or a war. By addressing the burning topic of infant and childhood deaths caused by the flaws of an adult system hurtling the world towards its ruin, Fuller's work contemplates various forms of reconstruction leaving room for hope. of course, denouncing does not mean repairing the damage, and the satirist all too often feels helpless when it comes to rebuilding a decent, harmonious world. However, both photographing and writing may play an important part in helping the survivors reconstruct a life and build a memory and a history for the victims.

3 The process of rebuilding in poetry-and in art at large-first implies witnessing, which will be the starting point of this study. As a matter of fact, unlike a construction created ex nihilo, a reconstruction comprehends our past, however painful it may be, to turn it into the future without ever erasing it. Although Fuller is not mentioned in anthologies about the poetry of witness, some of his texts do evidence extremity-whether of war or catastrophe-and the ensuing pain and chaos. Nevertheless, unlike authors like James Fenton, Fuller never was a war reporter bearing witness to tragedies in the field. His work thus questions the very codes of the poetry of witness. What role may a secondary witness, whose words and imagery mostly proceed from photography-not from direct commitment-, play in reconstructing the past of those who died too soon? To what extent can his verse sound authentic while he did not experience the suffering personally? Can art-and new quests for order and beauty-genuinely express woes without disrespecting the victims? If so, how does Fuller successfully achieve this goal? Even though he tackles grim subjects head on, his poetry nonetheless always remains lifeaffirming. Whenever death pervades his lines-"The chimneys have fired their guns"-, it also surprisingly acts as a foil to the creative power of children marvelling "[a]bout nothing at all".

\section{Witnessing Sacrificed Childhood}

On 21 October 1966, a coal slag tip from Merthyr Vale colliery collapsed in Aberfan, near Merthyr Tydfil in southern Wales, killing 116 children and 28 adults. Pupils at Pantglas Junior School were just beginning their first lessons when the landslide of mud and debris inundated their classroom. In an interview conducted by Graham Harrison, we learn that "David Hurn was in Bristol when he heard the news. He was with Ian Berry. The two photographers dropped what they were doing and drove [...] to Aberfan where between them they produced an eerie set of images of the rescue operation, and of the remnants of the deadly spoil heap still looming above the village" ("David Hurn" in Photo Histories). Ian Berry recalls the event, fifty years later:

When I got there it was already dark but they were still working madly to try to clear away all the debris to get at children and bodies. By the time I got there they weren't pulling out anybody who was still alive, they were just really recovering bodies and it was a pretty awful scene. It was a bit like after a bombing, everyone was fairly shocked, but they had sort of set-up, in that sort of Brit way, they were fairly organised, everybody was helping. (quoted in Havlin)

Laura Havlin notices that "following their assignment Ian Berry and David Hurn received a note from Magnum co-founder Henri Cartier-Bresson, saying that their photographic 
coverage of the Aberfan disaster was Magnum at its best. David Hurn, who became a Magnum nominee in 1964, was made a full member in 1967" (Havlin).

In Regarding the Pain of Others, Susan Sontag sets forth that "photographs are a means of making 'real' (or 'more real') matters that the privileged and the merely safe might prefer to ignore" (6). She insists on the importance of witnessing praised by the Magnum agency: "Magnum's charter [...] spelled out an enlarged, ethically weighted mission for photojournalists: to chronicle their own time, be it a time of war or a time of peace, as fair-minded witnesses free of chauvinistic prejudices" (31). This stance corroborates Hurn's own approach to documentary photography:

For a photographer, taking pictures during an emergency situation presents a conflict between the people experiencing the disaster [...] who do not want a photographer around, and performing a job that may prove to have not only historical but legal significance. Nobody can ever say it didn't happen or that it wasn't as bad as it was seen to be. (quoted in Havlin)

But once photographic evidence has been given, words become necessary for further explanation. Cartier-Bresson argues that " $[\mathrm{t}] \mathrm{he}$ camera is not the right instrument to provide the whys and wherefores of things; it is, rather, designed to evoke" (67), in line with Sontag's later remarks: "[h]arrowing photographs do not inevitably lose their power to shock. But they are not much help if the task is to understand. Narratives can make us understand. Photographs do something else: they haunt us" (80). More than forty years after the Aberfan disaster, Hurn's photos continued to haunt viewers, including John Fuller whose lines serve as an unsuspected caption of sorts to six pictures by Hurn ${ }^{1}$ (WP, 108-111). Whether they "can make us understand" the event remains a moot point, though, insofar as they question the traditional codes of witnessing.

According to Carolyn Forché and Duncan Wu, the poetry of witness is based both on the notion of "extremity" and on the way readers receive the text as a "testimonial presence" or "living archive" (26):

In conditions of extremity (war, suffering, struggle), the witness is in relation, and cannot remove him or herself. [...] The form of [his] language bears the trace of extremity, and may be comprised of fragments: questions, aphorisms, broken passages of lyric prose or poetry, quotations, dialogue, brief and lucid passages that may or may not resemble what previously had been written. [...] Ethical reading of such works does not inhere in assessing their truth value or efficacy as "representation", but rather in recognising their evidentiary nature: here language is a life-form, marked by human experience, and is also itself material evidence of that-which-occurred. (25)

So, to read a poem of witness "ethically", one must perceive the "evidentiary nature" of an event through language. But for Forché and $\mathrm{Wu}$, this implies that the poet first witnessed an extreme situation as a man or woman present in the field. The major difference with Fuller's poem lies in that it waives this rule by offering an unprecedented mise en abyme of witnessing: a secondary witness (the poet) gives a verbal translation of the work of a primary witness (the photographer) who was on the premises four decades earlier to provide "material evidence of that-which-occurred". In such a case, hindsight and indirection incite the poet to approach the catastrophe in a rather unusual way, running the risk of a lack of authenticity. However, one may contend that in this collaboration, Fuller's tour de force consisted in drawing authentic evidence out of the pictures by subtly rendering the feelings experienced by the victims and survivors appearing in the pictures, notably through "fragments, questions, quotations, etc." which sound like the locals' responses to the Aberfan catastrophe. Fuller has a knack for stepping in others' 
shoes, however different their lives may be from his, so that his secondary testimony of the disaster also "bears the trace of extremity", and we shall see how.

But first, it is important to stress that Hurn chose not to represent the victims. Moreover, in Writing the Picture the photos are uncaptioned, and the "List of Images" at the end of the book only indicates "Aberfan Disaster, 1966" (112). Besides, Fuller's text acts as an unsatisfactory form of caption since it only partly specifies what happened ("a mountain collapse", 1.28) in a rather vague context: "The last day of school before the holiday" (1.16). Any viewer or reader unaware of the Aberfan tragedy may sense that something serious took place but cannot guess what, or if there were casualties. As a consequence, the "catastrophe that is experienced [...] seem[s] eerily like its representation" (Sontag 19). Hurn's pictures are reminiscent of war scenes by Gerda Taro or Robert Capa that seem surreal whereas they are all too real, and Marc Aronson and Marina Budhos's comments on Taro and Capa's art could relevantly apply to Hurn's first picture representing the landslide in a high-angle shot with an empty valley in the background:

Under chilly grey skies, they move on, venturing into the ravaged parts [...]. There's a quiet stillness to the work they produce [...]. Their photographs reflect a sense of shock at what they see: a city shorn, emptied out, ruined. [...] "Surrealism," they write in their notebook-the city reminds them of the art of nightmare, séance and dream created by painters such as Salvador Dalí. (117-118)

Likewise, Hurn's photo "reflect[s] a sense of shock at what [he] see[s]", an almost surreal "quiet stillness". Imposing itself as an invisible "trace of extremity", the eerie silence is further underlined in the last lines of the poem:

As we wander the streets like lost souls

Endlessly and for our lifetime can be heard

Neither a child nor a bird.

Not only does the pronoun "we" encompass the surviving locals and the photographers "wander[ing] the streets" to cover the event; but given the present tense chosen in this sentence, it also includes the poet, decades later, and us, readers, attending the disaster as if in medias res. Fuller remembers reading that the silence of the birds was a fact remarked by witnesses. ${ }^{2}$ By integrating it into the lines, he forcefully brings it back to the present of each reading, as though time had been suspended since this extreme situation.

Both the pictures and the lines approach the subject of death indirectly, through an aesthetics of suggestion, restraint, and deep respect for the victims. Hurn's pictures show compassion for the survivors united in the aftermath of the coal slip. In this regard, the most striking photo is the third one portraying two surviving children taken from behind. As they are in the foreground and at the top of a hill overlooking the miners digging, the viewers enter the scene through their eyes, so that it is even easier for us to imagine what they have just gone through. The other pictures emphasise a sense of reunion and solidarity centred on the slurry-hence on the buried corpses-, particularly the two photos at the bottom of pages 108 and 109 where the lines of men form triangles pointing to the fallen walls of the school and framing vacant spaces probably hiding corpses. Never are the villagers overexposed. They surely look tired and anxious, but the photos also spotlight their moral force and bravery, and their ability to organise efficiently in the midst of chaos. They know that the photographer is there, but they forget, in the course of action, because he immediately earns their trust. Capa's simple advice to be a good photographer-"like people and let them know it" (Aronson \& Budhos 65)-tallies with Hurn's in On Looking at Photographs: "there is no substitute in photography for a loving, caring, knowledgeable empathy with the subject in front of the 
camera" (81). And once again, Aronson and Budhos's remarks about Capa's photography are transferable to Hurn's:

To get close as a photographer is both to put on the armor of bravery and to leave yourself open to feel, to connect, with whomever or whatever you see. [...] The photographer's challenge is to find the balance between the "magnificent act" of bravery and the "softness" within-the tender part of the self that feels urgently for the people being photographed. Getting close is not just about the action shot-it is about connecting emotionally, finding the heart of a devastating and violent scene.

(Aronson \& Budhos 148-149)

Beyond the descriptions or ekphrases proper-which are not that obvious in this poem-, Fuller's lines disclose "the tender part of the self that feels urgently for the people". Driven by a genuine altruistic impetus, his multifaceted speaker adopts various viewpoints warranting a strong capacity for empathy. For example, the first quatrain comprises at least four complementary perspectives: we can first visualise the miners' thoughts as they are digging with their "spade in the slurry", but also both the surviving "children's [anxious] faces" and the dead "children's faces" during the landslide, as well as all the witnesses' expressions, including "ours deep with questions":

The flinch of the spade in the slurry,

The image of children's faces.

Bright and beautiful, their dark eyes

Search ours deep with questions:

The simple syntax allows the text to unfold like a series of slides projecting fear while trying to express the victims' experience just before death. The following questions are all the more disturbing because they let dead voices be heard, as in a nightmare:

What is the black outside the window?

What is the sound that is also a feeling?

What is that weight against the door?

What is that trembling between my feet and the floor?

Where is the light? Where is the ceiling?

The choice of a succession of unanswered questions is both harrowing and uncanny as it shatters all solid bearings and blurs the boundaries between life and death, as in a prosopopoeia. Synesthesia adds to the sense of loss and dread. For instance, not only does "the sound that is also a feeling" refer to the external rumbling of the descending slurry, but it also evokes a subliminal trembling of the falling coal-waste covering the buildings as well as the sudden angst overbearing the villagers. But then the poet realises that he has taken us to the limits of representation:

Until we can't imagine their questions any more

And the questions are all in our own heads.

Isolated between two blank spaces loaded with tense silence, this couplet bespeaks failure in fully grasping the horror of extremity, either visually or verbally.

\section{Denouncing, Remembering}

When witnessing, neither photography nor writing contributes to rebuilding. "To designate a hell is not, of course, to tell us anything about how to extract people from that hell, how to moderate hell's flames" (Sontag 102). However, the "testimonial presence" of photography undeniably incites the poet to denounce culprits, which is an important step towards reconstruction:

The faithlessness, the failure of calculation,

The ignoring of warnings, the passing of responsibility, 
The mindfulness of sums of money,

The concealment in the official reply, the cautious "perhaps".

Anger and weariness are here heightened by the juxtaposition of seven nominal groups in a nonverbal sentence. Fuller's accusations are all the more hard-hitting as they do not name anyone, thus prompting the readers to conduct their own investigation and learn that "the National Coal Board said abnormal rainfall had caused the coal waste to move [and that] the Inquiry of Tribunal later found that the NCB was wholly to blame and should pay compensation for loss and personal injuries" (Havlin). Besides, contrary to a press article or a pamphlet, Fuller's satirical undertone reaches beyond the immediate context of the Aberfan catastrophe. In these lines, the absence of spatiotemporal landmarks gives a universal value to a scene unfortunately bound to repeat itself over the years, as men fail to learn from past mistakes-witness Ben Okri's lines composed just after the Grenfell Tower fire:

Sometimes it takes an image to wake up a nation

From its secret shame. And here it is every name

of someone burnt to death, on the stairs or in their room,

Who had no idea what they died for, or how they were betrayed.

They did not die when they died; their deaths happened long

Before. It happened in the minds of people who never saw

Them. It happened in the profit margins. It happened

In the laws. They died because money could be saved and made. (Okri)

Once they have exposed the faults of a nation disregarding or despising its most vulnerable subjects, the artists also play an important part in building up its memory, its history - "Sometimes it takes an image" to remember the "secret shame" of a nation:

The familiarity of certain photographs builds our sense of the present and immediate past. Photographs lay down routes of references, and serve as totems of causes [...]. And photographs help construct-and revise-our sense of a more distant past [...]. Photographs that everyone recognizes are now a constituent part of what a society chooses to think about, or declares that it has chosen to think about. (Sontag 76)

In Writing the Picture, however, the photographs that the reader learns to recognize are a constituent of what the poet, not society, chooses to think about. As a secondary witness, he invites us to reconsider a dark side of history that we may not be aware of, reminding us that over the long run "memories" become a fiction. "Strictly speaking, there is no such thing as collective memory [...]. But there is collective instruction" (Sontag 76). One of the poet's public duties is to go on "instructing" us about others' pain, through fictionalized-yet emotionally genuine-memories if necessary:

What was it that we left unsaid

The last time we saw them, the hasty hug,

Cheek to the apron, arms reaching round the waist,

Grabbing books and out of the door,

The last day of school before the holiday?

Wise and wonderful, their last words

Haunt us like the shining of flannelled faces

To be blinded in the darkness.

In these stanzas, Fuller uses direct speech, the words sounding like fragments of conversation the victims' parents may have had just after the disaster and years later. Paradoxically enough, fiction allows him to channel emotion in order to express an even more authentic, collective despair and grief, striking a chord with all families in mourning. 
11 Furthermore, disturbing though they may be, both Hurn's and Fuller's works are beautiful. Although finding beauty in ghastly photographs might seem heartless, "the landscape of devastation is still a landscape. There is beauty in ruins. [...] Transforming is what art does, but photography that bears witness to the calamitous and the reprehensible is much criticized if it seems "aesthetic" (Sontag 67-68). Hurn openly claims that "the photographer's aim is to create beautiful pictures, of any and all subject matter" (Hurn \& Jay 69). His admiration for Sebastião Salgado's or Ian Berry's chaotic landscapes testifies to his own conception of the beauty of desolation:

The extraordinary ability of photographers like Ian Berry or Sebastião Salgado is that they could shoot pictures in the same situation alongside many other photographers of lesser ability and not clearly reveal the chaos but also produce images of power which so impress themselves on your consciousness that they are never forgotten. That's what I would call good design, which is inseparable from good photography. (Hurn \& Jay 68)

Hurn's Aberfan pictures equally "produce images of power" that elevate their subjects to the status of heroes digging for their "children's faces / Fiercely, cautiously, as for a tender crop" (1.34-35). The artful compositions enhance the dignity of the miners while the delicate chiaroscuro effects, especially in the fifth and sixth pictures (WP, 111), imbue the scenes with solemnity and command respect. Reportage photography is thereby changed into a photographic tribute paid to the victims and their families through "good design". On this point, Robert Adams's ${ }^{3}$ praise of Frank Gohlke's pictures of a tornado that devastated Texas in 1979 perfectly matches Hurn's convictions: “Gohlke's pictures, although they too make clear the devastation, show order. His composition implies a belief in the endurance of shape; the pictures are metaphor, an assertion of meaning within the apocalypse. [...] It is his vision of form that is his chief gift to [...] survivors" (100). And Fuller's lines do "make clear the devastation"-partly reflected in the absence of rhyme patterns or regular metre-, while asserting "a belief in the endurance of shape" through numerous inner repetitions and anaphora. In addition, the diatribe and satire are underpinned by a deeper subtext which resonates like a distant, but no less poignant, homage to the dead children-"Bright and beautiful" (1.3), "Wise and wonderful" (1.17)echoing Cecil Frances Alexander's famous hymn (27):

All things bright and beautiful,

All creatures great and small,

All things wise and wonderful,

The Lord God made them all.

Nevertheless, the tone in Fuller's parody of Alexander's lines is in turn tender, falsely ingenuous and undoubtedly cynical in a context where "[a]ll creatures great and small" are also likely to commit atrocities.

\section{Children at War}

In his "Letter to John Fuller" (1972), James Fenton advocates his friend's "sane" poetry: "Look you, / John Fuller, I admire your book. You / Write well, though sanely" (68). In reaction against extreme confessional modes betraying a writer's emotional disturbance, Fenton reveres tact, energetic inventiveness, and "a mode of representation more interested in the possibilities for poetry of novelistic fiction than those of psychoanalytical therapy" (Corcoran 246). Seamus Heaney notes that Fenton addresses international disasters through renewed "common sense and understatement"-i.e. "sane" but still very powerful verse: 
[I]n his "Letter to John Fuller", [Fenton] was marking the desire of poets to regroup around the aesthetic of "common sense and understatement". Using the stanza form of Robert Burns with its insinuating cadence, its emphasis on poetry as a kind of social bonding, was the formal expression of resistance and retrenchment. [...] By addressing [the "Letter"] to John Fuller, one of the most stylish poets around [...] Fenton drew a line, marked the ground he would play on, re-established the borders of a civil kingdom of letters where history and literature and the intimate affections would be allowed their say. (Heaney)

Fenton worked as a reporter in Vietnam and Germany, and these experiences resurface in his lines. Yet Heaney insists that his poetry "recognizes the dimensions of apocalypse but conducts itself in a more or less orderly [...] polite [...] decent style" (Heaney). In his turn, Fuller commends Fenton's balanced poetics of restraint originating from on-field action:

Some day I'll join you in the street

Where suffering and truth must meet:

It isn't easy not to feel effete

This side of anguish,

When those who can't choose what to eat

Don't speak our language.

(Fuller 1996, 93)

In Fuller's answer to Fenton, the double negative ("It isn't easy not to feel effete") conceals an embarrassment at having more than enough when many have nothing, so that even directly accusing yourself of being effete is a kind of luxury. In other words, expressing others' pain might easily ring hollow-and almost unethical-unless the poet was directly faced with it, and is concerned about never "evading" his subject:

And so you need a form to play

About in but which will convey

Something of what you want to say

Without evasion

(Fuller 1996, 92)

One may put forward that when he started collaborating with Hurn in the 1980s, Fuller did eventually "join [his colleague] in the street", as the Aberfan poem attests. But the specificity and originality of his "street" is that it is a photographed one. Aware of suffering elsewhere in the world, he found new forms directly stemming from images and reportage that would "convey / Something of what [he] want[ed] to say" without qualifying as a war poet stricto sensu. For instance, his poetry of the 1990s dwells on the fate of child soldiers, and his chronicle of the Bosnian War in the sonnet sequence “Europe" chimes with Fenton's work:

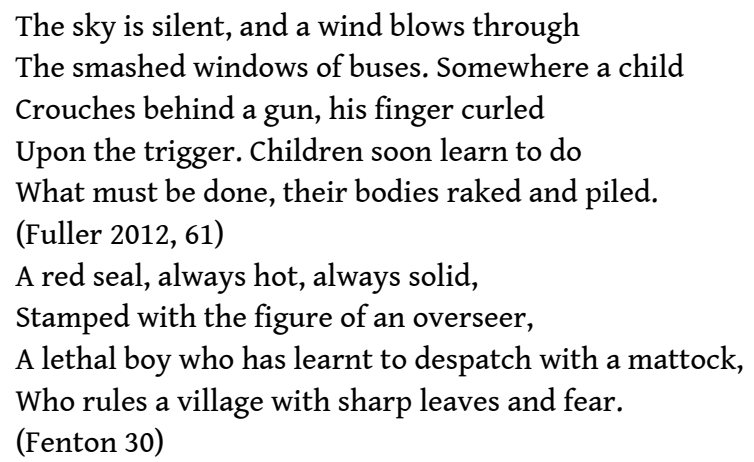

By indicating "Corsica, August 1992" at the end of "Europe" (61), Fuller underlines that he was not in the Balkans during the conflict. In an interview with John Walsh, he explains how haunted he was by the photos of reporters covering the war: 
I was very affected by the Bosnian conflict right back in its early days, say 1991/2. I found myself profoundly affected by things I was reading about and seeing-in particular, a photograph of someone having their head cut off with a saw. I was on holiday in Corsica at the time, just lounging around, and started writing these sonnets. It was something to do with the distance I was from home, about being in the Mediterranean, in the middle of Europe, and being able suddenly to think about the place in some kind of perspective [...]. (Walsh)

Paradoxically enough, distance allowed the poet to better grasp his topic and make it sound even more genuine, almost cinematic, as though unfolding before the reader's eyes: "Somewhere a child / Crouches behind a gun". The enjambment here delays and highlights the contrast between the vulnerability implied in crouching and the gun replacing a toy. Moreover, both Fuller and Fenton point out an adult system-"the figure of an overseer"- dehumanizing the children and programming them like war machines. In Fuller's lines, the modal auxiliary "must" coupled with the passive forms hardly leaves any hope to rebuild a life after the brainwashing. Altogether, the satire against the backdrop of Fuller's sonnet complements Fenton's thus summarized by Sara Greaves:

Most of the numerous children portrayed in [Fenton's poems] are in danger. They appear exposed at the forefront of war scenes, somehow sacrificed by the adults around them. [...] Some have been indoctrinated and instrumentalised: "And I had learnt enough, my friend, / To believe what I was told" ("Out of the East"). Others are introduced into a harmful cycle of revenge: "The child who saw his father's killer killed / Has slaughtered half of the children in the land" ("The Ballad of the Imam and the Shah"). Fenton presents us with a political world in crisis, where adults fail to accomplish their duties towards children. (80-81, my translation)

In "Siege" (November 2016), a more recent poem about Gaza and today's conflicts, Fuller deals with the issue of children at war from the viewpoint of a mother evocative of a Pietà or one of Euripides' tragic heroines like Andromache:

This is my child, who will never wake,

Patrolling the streets with a ready gun,

Waiting with explosives in a tunnel,

Doing what is done with human hands,

The fruit spilling from the market carts. (Fuller 2016)

By erasing the distinction between life and death, this stanza calls for several interpretations. Beyond the child's literal death in the conflict, we are also strangely presented with yet another case of victims who "did not die when they died; their deaths happened long / Before" (Okri), since they were caught in a vicious adult cycle as soon as they were born. In this respect, although some of the child soldiers may stay alive, they "will never wake" up as themselves because they have been deprived of their childhood. They strangely appear as ghosts of themselves in a world where "human hands"-i.e. human evil, not animal instinct-turned them into living dead; and where birth ("The fruit") becomes synonymous with blood sacrificed ("spilling") on a daily basis in the degraded temples ("the market") of ruined cities:

The apartments are sliced open like a doll's house,

The families in dust, as stiff as dolls,

Children in rubble, unusually still.

In the hospitals, the surgeons in despair,

The beds themselves under rubble,

A thigh stump like a burst pomegranate. (Fuller 2016)

"Siege" was written in response to a request from the British composer Nicola LeFanu, whose concertante work for soprano and orchestra (entitled "The Crimson Bird") had been commissioned by the Royal Philharmonic Society. The premiere was given by the BBC 
Symphony Orchestra on 17 February 2017 at the Barbican Centre, London. LeFanu rearranged the order of Fuller's lines so that they more adequately suited her score. However, the description of the bombed apartments does not appear in the text printed in the programme notes sold before the concert. And yet, the soprano Rachel Nicholls unexpectedly recited (without singing) these lines during the performance. LeFanu's decision to integrate them somehow into her piece is quite telling. For one thing, it evidences their crucial part within the poem. For another, it betrays the limits to music when it comes to expressing the havoc wrought by war. It obviously mattered to LeFanu that these precise words could be clearly understood, and not hushed up by the orchestra like most of the lyrics. Therefore, oddly enough, for a few minutes during the concertante, it is sudden silence-and not music-, followed by solemn recitation, that mirrors today's warfare in the Middle East. Both Fuller and LeFanu reject all forms of understatement or embellishment of horror. In sharp contrast with the aesthetic choices made in the Aberfan poem, Fuller lays emphasis on the raw materiality of death ("stiff as dolls", "unusually still", "A thigh stump") and the hopeless urgency of the situation ("the surgeons in despair"). Inner echoes ("rubble", "dust"/"burst") force the audience to visualize the war scene before the orchestra alleviates the extreme tension backed up by the soprano's slow diction.

Any hope to reconstruct lost childhood thus proves unthinkable at such a point in Fuller's poem. The heavy silence spreading between the lines does nothing but shore up the poet's powerlessness once the facts have been stated bluntly, as he confessed in an interview with Alex Clark: "I feel in my heart quite radical, but entirely, self-defeatingly, powerless to know how I would do anything about it" (Clark). And yet, if "poetry makes nothing happen", as his mentor W.H. Auden (to whom John Fuller dedicated a major work, see Fuller 1998) famously declared in 1939, it nonetheless "survives, / A way of happening, a mouth" (248). Neither Fuller's poetry nor LeFanu's music will change the course of History, but they do offer escapes at the very heart of chaos, by extolling naïve, innocent similes-“like a doll's house", "as dolls", "like a burst pomegranate"-allowing momentary flights back to childhood, back to a wonderland of toys, games and tasty exotic fruit, precisely when the world of adults does not make sense anymore.

\section{Conclusion: Rebuilding Childhood by Capturing the Energy of Youth}

In Writing the Picture, three photos devoted to football (WP, 86-87) epitomise Hurn's own conception of beauty: "[f]or me, most photographs displaying beauty reveal a sensation of strangeness, not predictability, a kind of shock non-recognition inside the familiar" (Hurn \& Jay 70). The caption on the Magnum Photos website tells us that the snapshot on the left was taken in "spare land in front of East Moors steel works at the time that the steel works were closed. Perhaps [the children's] fathers are now out of work. Cardiff. 1978". So, in this example, the "familiar" is associated with a bleak, dour context of industrial crisis. Yet two among the young players are almost literally flying in the air, floating just like the ball, or the smoke and clouds in the background, with the balletic grace of Nijinski or Nureyev. They were caught taking off at what Cartier-Bresson calls "the decisive moment": "inside movement there is one moment at which the elements in motion are in balance. Photography must seize upon this moment and hold immobile the equilibrium of it" (33). The burst of energy and youth brought by their improvised soccer 
match gives rise to "a kind of shock non-recognition" contrasting with the ghostly extinct chimneys and massive towers.

The players in the three photos are momentarily taken out of human time by happily abiding by the rules of the game:

There is no doubt that play must be defined as a free and voluntary activity, a source of joy and amusement. [...] As an obligation or simply an order, it would lose one of its basic characteristics: the fact that the player devotes himself spontaneously to the game, of his free will and for his pleasure, each time completely free to choose retreat, silence, meditation, idle solitude, or creative activity. From this is derived Valéry's proposed definition of play: it occurs when "l'ennui peut délier ce que l'entrain avait lié". It happens only when the players have a desire to play, and play the most absorbing, exhausting game in order to find diversion, escape from responsibility and routine. [...] In effect, play is essentially a separate occupation, carefully isolated from the rest of life. (Caillois 6)

Fuller's lines exemplify Caillois's definition while reinforcing the sense of selfforgetfulness induced by football through the use of the pronoun "you" (instead of "I" or "we") suggesting that the speaker addresses another self, like a double of himself entirely engrossed in the game, and able to rebuild his childhood out of nothing:

The goal needn't be much,

A stone or a folded coat

Or just the air behind you,

Wishing you were tall,

Wishing you could float.

(WP, 86)

The last two lines capture the energy displayed in the scenes through a series of monosyllables enhancing the sensations of freedom and empowerment experienced by both the young players and the older poet "once he gets the ball[-point]":

But nobody can touch you

Once you get the ball.

Roni Natov marks that "[t]he poetics of childhood represents both the reader and the writer, the creator and the witness to the creation, the potential of even our darkest moments of dislocation to metamorphose into a rejuvenating and creative energy" (7). Neither Hurn nor Fuller neglects forsaken children whom they commemorate in works that also condemn the failings of their adult environment. But they never give in to despair, however gruesome their subject. And children, as guides to their photos and texts, remain a source of hope, suggesting that "no matter how devastating the world, healing can come through the use of childhood to create a poetics, an imagined but tangible state, inspired and illuminated by the child, to return to" (Natov 7).

\section{BIBLIOGRAPHY}

Adams, Robert. Beauty in Photography. New York: Aperture, 1996.

Alexander, Cecil Frances. Hymns for Little Children (1848). London: Forgotten Books, 2015. 
Aronson, Marc, and Marina Budhos. Eyes of the World: Robert Capa, Gerda Taro, and the Invention of Modern Photojournalism. New York: Henry Holt and Company, 2017.

Auden, Wystan Hugh. Collected Poems (1976). Ed. Edward Mendelson. London: Faber \& Faber, 1994.

Caillois, Roger. Man, Play and Games (1958). Trans. Meyer Barash. Champaign: U of Illinois P, 2001.

Cartier-Bresson, Henri. The Mind's Eye: Writings on Photography and Photographers. Trans. Diana C. Stoll. New York: Aperture, 1999.

Clark, Alex. "Interview. John Fuller: 'I feel in my heart quite radical but powerless to do anything about it.” The Guardian (7 January 2017). https://www.theguardian.com/books/2017/jan/07/ john-fuller-interview-poet-novelist-mortality-beat-generation-open-mic-sessions (last accessed 31 January 2019).

Corcoran, Neil. English Poetry since 1940. London: Longman, 1993.

“David Hurn”. Photo Histories. The Photographers' History of Photography. http:// www.photohistories.com/interviews/56/david-hurn (last accessed 31 January 2019).

Fenton, James. The Memory of War and Children in Exile: Poems 1968-1983. London: Penguin Books, 1983.

Forché, Carolyn, and Duncan Wu. Poetry of Witness: The Tradition in English 1500-2001. New York: Norton, 2014.

Fuller, John. Collected Poems. London: Chatto \& Windus, 1996.

Fuller, John. W.H. Auden: A Commentary. Princeton: Princeton UP, 1998.

Fuller, John. New Selected Poems. London: Chatto \& Windus, 2012.

Fuller, John. “Siege”. Standpoint (November 2016). http://www.standpointmag.co.uk/ node/6671/full (last accessed 31 January 2019).

Fuller, John and David Hurn. Writing the Picture. Bridgend, Wales: Seren, 2010.

Greaves, Sara. Côté guerre Côté jardin : Excursions dans la poésie de James Fenton. Aix-en-Provence: PU de Provence, 2016.

Havlin, Laura. “Aberfan: the Village that Lost a Generation”. https://www.magnumphotos.com/ newsroom/aberfan/ (last accessed 31 January 2019).

Heaney, Seamus. "Making it New (Review of Children in Exile: Poems 1964-1984 by James Fenton)". The New Yorker (October 25, 1984). https://www.nybooks.com/articles/1984/10/25/making-itnew/ (last accessed 31 January 2019).

Hurn, David, Jay, Bill. On Being a Photographer. Anacortes: LensWork Publishing, 2009.

Natov, Roni. The Poetics of Childhood. New York: Routledge, 2006.

Okri, Ben. “Grenfell Tower, June 2017: a poem”. https://www.ft.com/ content/39022f72-5742-11e7-80b6-9bfa4c1f83d2 (last accessed 31 January 2019).

Sontag, Susan. Regarding the Pain of Others (2003). London: Penguin Books, 2004.

Walsh, John. “John Walsh meets... John Fuller”. The Independent (12 October 1996), https:// www.independent.co.uk/life-style/john-walsh-meets-john-fuller-1357897.html (last accessed 31 January 2019). 


\section{NOTES}

1. Almost all the photos published in Writing the Picture can be found on the following website: https://pro.magnumphotos.com/C.aspx?VP3=SearchResult\&ALID=2K1HRGMDC8Y (last accessed 31 January 2019).

2. I am grateful to John Fuller for sending this information to me in an email dated 26 July 2017.

3. David Hurn recommends Adams's essay on his Instagram account.

\section{ABSTRACTS}

This article investigates John Fuller's poetry for adults about children through close readings of texts inspired mostly by David Hurn's photography or commissioned by a composer. However dexterously Fuller's work may translate the creative potential of childhood, there is no denying that it also shows deep concern about those whose lives were sacrificed too early, be they the victims of an industrial downturn, a catastrophe or war. Fuller's lines question the codes of the poetry of witness: to what extent may a poet who wasn't in the field to observe a crisis genuinely bear witness to the flaws of the adult world? What part-if any-can he play in rebuilding ruined lives? Once the satirist has exposed the absurdity of a collapsing system, his words might help commemorate the victims and build them a collective memory, but their political role in reshaping the world is undeniably limited. "I feel in my heart quite radical, but entirely, selfdefeatingly, powerless to know how I would do anything about it", says the poet, who nonetheless never overindulges in doomsaying. Instead, his verse never ceases to celebrate the strength of childhood by capturing children's spontaneity and breathing their energy into lifeaffirming lines.

Cet article aborde l'enfance dans la poésie pour adultes de John Fuller à travers l'analyse de textes inspirés essentiellement de la photographie de David Hurn ou composés pour être mis en musique. Si Fuller traduit avec brio l'énergie créatrice inhérente à l'enfance, ses vers dressent par ailleurs des portraits d'enfants sacrifiés grandissant en temps de crise industrielle, disparus à la suite d'une catastrophe ou victimes d'une guerre. Ils interrogent les codes de la poésie du témoignage: dans quelle mesure un écrivain n'ayant pas vécu une situation chaotique in situ peut-il témoigner authentiquement des fautes perpétrées par les adultes ? Comment œuvre-t-il à la reconstruction des vies ruinées? Le satiriste peut certes commémorer les victimes, voire contribuer à leur construire une mémoire collective. Mais il n'en est pas moins pleinement conscient de l'impact politique limité de ses mots : « je suis radical dans mes prises de position les plus personnelles, mais je me sens totalement impuissant et désarmé quand il s'agit de passer à l'action ", déclare le poète, sans jamais néanmoins se complaire dans le défaitisme. Au contraire, ses poèmes n'ont de cesse de célébrer la force de l'enfance. Ils s'emploient à saisir la spontanéité des enfants avant de la retranscrire dans des vers d'une vitalité sans pareille. 


\section{INDEX}

Mots-clés: crise, enfance, photographie, guerre, témoignage

Keywords: childhood, crisis, photography, war, witness

\section{AUTHORS}

\section{AURÉLIEN SABY}

Aurélien Saby earned a PhD in literature from Sorbonne University in 2013. He wrote his dissertation on the work of W.H. Auden. He teaches English at lycée Hélène Boucher in Paris and is a member of the VALE Research Centre (Sorbonne University). He published several articles dedicated to W.H. Auden, John Fuller and David Hurn, including “'Don't look at me, don't look' I'm doing wrong... to myself! A Poetic Approach to Drug Addiction by John Fuller and David Hurn" (Wrongdoing, ed. Élizabeth Durot-Boucé, Rennes : Tir, 2015), « W.H. Auden and the Mezzogiorno » (Literature and Geography: The Writing of Space throughout History, ed. Emmanuelle Peraldo, Newcastle-upon-Tyne, Cambridge Scholars, 2016), « Lecture de "Down There" de W.H. Auden : de la cave des origines au retour de la guerre » (Polysèmes 16 | 2016, URL: http:// journals.openedition.org/polysemes/1517), "W.H. Auden and the Poetics of Transport" (Études anglaises 69/4 [octobre-décembre 2016]), and "The Uncanny in Writing the Picture (2010) by John Fuller and David Hurn" (Études écossaises 19 | 2017, URL: http://etudesecossaises.revues.org/1306 ). 